\title{
Estrogen Receptor Beta
}

National Cancer Institute

\section{Source}

National Cancer Institute. Estrogen Receptor Beta. NCI Thesaurus. Code C38364.

Estrogen receptor beta ( $530 \mathrm{aa}, \sim 59 \mathrm{kDa}$ ) is encoded by the human ESR2 gene. This protein is involved in the modulation of transcription of estrogen-responsive genes. 